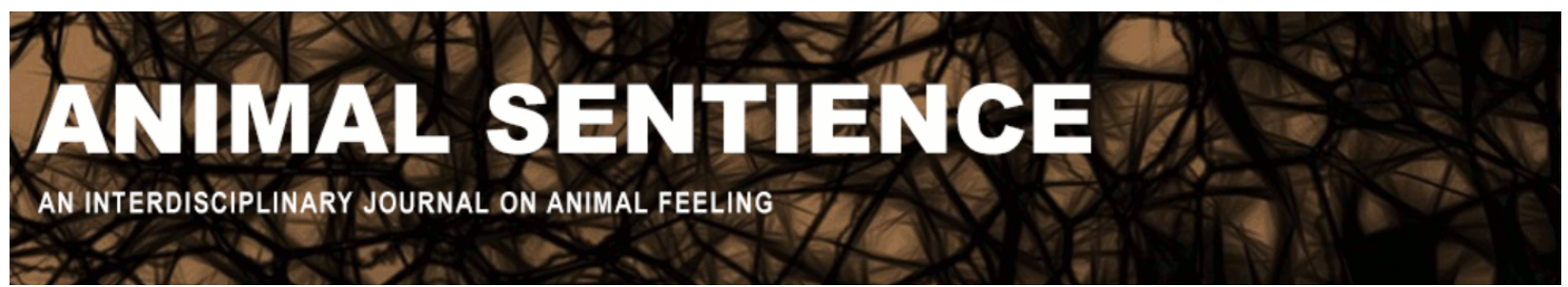

Johannsen, Kyle (2019) Are some animals also moral agents?. Animal Sentience 23(27)

DOI: $10.51291 / 2377-7478.1404$

Date of submission: 2019-02-06

Date of acceptance: 2019-02-18

(c)

This article has appeared in the journal Animal

Sentience, a peer-reviewed journal on animal

cognition and feeling. It has been made open access,

free for all, by WellBeing International and deposited

in the WBI Studies Repository. For more information,

please contact

wbisr-info@wellbeingintl.org.

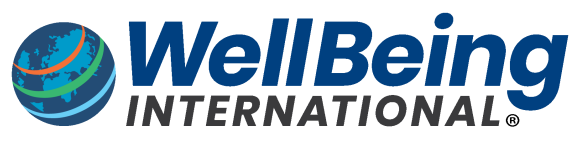

SOLUTIONS FOR PEOPLE, ANIMALS AND ENVIRONMENT 


\title{
Are some animals also moral agents?
}

Commentary on Chapman \& Huffman on Human Difference

\author{
Kyle Johannsen \\ Department of Philosophy \\ Trent University
}

\begin{abstract}
Animal rights philosophers have traditionally accepted the claim that human beings are unique, but rejected the claim that our uniqueness justifies denying animals moral rights. Humans were thought to be unique specifically because we possess moral agency. In this commentary, I explore the claim that some nonhuman animals are also moral agents, and I take note of its counter-intuitive implications.
\end{abstract}

Kyle Johannsen is an instructor in the philosophy department at Trent University. His areas of specialization are political philosophy and animal ethics, and he is particularly interested in questions about distributive justice and about wild animal suffering. Website

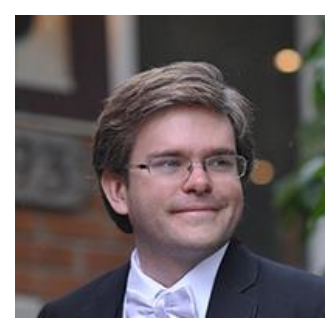

Chapman \& Huffman (2018) correctly note that the claim that human beings are unique has been used to try to justify atrocious actions and institutions, e.g., hunting, experimentation, and animal agriculture. In addition, they offer a number of reasons for believing that humans' claim to uniqueness should be rejected. On their view, human beings are only unique in the same way that any particular species is different from other species. Although I am sympathetic to their argument, I am reluctant to give up the idea that there is a special way in which human beings are different from other species. In the philosophical literature on animals, it is conventional to distinguish between moral agents and moral patients, and to categorize human beings as agents and nonhuman animals as patients (Regan, 2004). Before we accept the claim that some animals are agents, too, we should take a close look at its implications.

In her commentary, Juergens (2018) notes that one way in which we are special is that we bear a moral responsibility to avoid causing harm (including harm to the environment), and that when we fail to fulfill this responsibility, we are responsible for rectifying the harms we have caused. Although Juergens does not use philosophical terminology, moral agency is what she is talking about. To put it simply, moral agency is the capacity to make choices for which one can be held morally responsible. Moral agents have the ability to understand moral reasons and to engage in moral dialogue, and thus they also have the ability to distinguish right actions from wrong actions. Because they possess these abilities, it is appropriate to ascribe moral duties to agents, and to blame them when they fail to fulfill these duties.

Traditionally, philosophers who maintain that animals have moral rights, such as the right to life, have been willing to concede that animals are not moral agents. Though animals have morally significant interests that warrant moral rights, e.g., interests in avoiding suffering and in satisfying their preferences, the conventional view is that animals do not owe duties to other 
rights bearers. Since animals are owed obligations but do not owe obligations, they have been labeled 'moral patients.' Examples of moral patients in the human case include human infants and people with severe dementia.

Embedded in the distinction between human agents and animal patients is a particular version of the claim that human beings are unique. This uniqueness is different from superiority, however. The interests of animals matter just as much as the interests of human beings, and animals' lack of agency is no good reason to think otherwise (Singer, 1975). After all, we do not think that the absence of agency deprives someone of moral status in the human case. The interests of infants and people with severe dementia matter just as much as the interests of other human beings.

Although the distinction between human agents and animal patients was long accepted in the animal ethics literature, the claim that animals lack agency has received criticism in recent years. It has been argued that many domesticated animals possess the cognitive capacities associated with agency (Donaldson \& Kymlicka, 2011), and there is certainly a case to be made for the claim that great apes, whales, and dolphins do, too (Fields, 2008; Andrews et al., 2018). Whereas it would be implausible to claim that most animals are moral agents, some animals might be. And if some animals are moral agents, then the claim that human beings' agency makes humans unique is no longer sustainable. The distinction between human agents and animal patients would have to be replaced by a distinction between animals who are agents (humans included) and animals who are patients.

Though some nonhuman animals possess very impressive cognitive abilities, we should pause for a moment and consider what attributing moral agency to them implies. I have no doubt that great apes, whales, and dolphins have morally significant interests (just as other animals do), but should we be holding them morally responsible for their behavior? Should, for example, whales and apes who harm other sentient beings be morally blamed? After all, whales and apes do harm other sentient beings. Orcas, for example, eat both fish and various sea mammals. And chimpanzees, for example, are omnivores whose diet is partially composed of meat from animals they have killed (Fahy et al., 2013). If it seems inappropriate to blame orcas and chimpanzees for such behavior, then we should be reluctant to ascribe moral agency to them.

There may be an easy way around the problem I have highlighted. We might say that the nonhuman animals who possess agency are only partial agents, not full agents. Or we might say that the sort of agency they possess is different from moral agency - that they can make meaningful choices about how to act (they are not simply biological robots), but that they nonetheless lack the cognitive abilities necessary to be morally responsible for those choices. Of course, taking this route means leaving intact the claim that our moral agency makes us special. 


\section{References}

Andrews, K., Comstock, G.L., Crozier, G.K.D., Donaldson, S., Fenton, A., John, T.M., Johnson, L.S.M., Jones, R.C., Kymlicka, W., Meynell, L., Nobis, N., Pena-Guzman, D., \& Sebo, J. (2018) Chimpanzee rights: The philosophers' brief. London: Routledge.

Chapman, C.A., \& Huffman, M.A. (2018) Why do we want to think humans are different? Animal Sentience 23(1).

Donaldson, S., \& Kymlicka, W. (2011) Zoopolis: A political theory of animal rights. New York: Oxford University Press.

Fahy, G.E., Richards, M., Riedel, J., Hublin, JJ., \& Boesch, C. (2013) Stable isotope evidence of meat eating and hunting specialization in adult male chimpanzees. PNAS 201221991.

Fields, R.D. (2008) Are whales smarter than we are? Scientific American: Mind Matters.

Juergen, U.M. (2018) Human and nonhuman animals: Equals in uniqueness. Animal Sentience 23(2).

Regan, T. (1983) The case for animal rights. Los Angeles: University of California Press.

Singer, S. (1975) Animal liberation: A new ethics for our treatment of animals. New York: Avon Books. 